\title{
Construcción de una narración en el espacio
}

\section{Jorge Vidal}

Recibido 2019.09.23 ::: Aceptado 2019.09.26

DOI: 10.5821/palimpsesto.20.8952

Persona de contacto: jorge@jorgevidal.eu

ORCID: https://orcid.org/0000-0001-7136-9348

Arquitecto por la ETSAB

\begin{abstract}
provecho este espacio de la revista Palimpsesto para celebrar y agradecer los años como profesor al lado de Carlos Ferrater y Alberto Peñin. Estuvimos juntos en los cursos de proyectos III-IV de la Escuela Superior de Arquitectura de Barcelona desde el año 2008 hasta el 2018. También fui profesor del Master de proyectos XXI que ellos dirigían entre los años 2008 y 2010. En total fueron 10 años juntos impartiendo docencia que marcaron mi trayectoria. Críticas intermedias y finales con otros profesores del curso como Víctor Rahola, con el que aprendí la profesión de arquitecto trabajando 9 años juntos, o Albert Illescas con el que tuve el placer de compartir taller de proyectos. Disfruté de su pasión por la arquitectura y la escuela. De él aprendí gran parte de lo que sé sobre la enseñanza.
\end{abstract}

En palabras de Albert:

“El millor d'ensenyar a l'escola són els alumnes. A l'Escola estem per compartir amb els alumnes un tram del cami cap l'arquitectura, i per ensenyar com fer-ho. I en alguna ocasió sentir el "clic" que els transforma en probables -bonsarquitectes. Aquest procés, a la classe on veniu sovint de forma obligatòria, per sorteig, i on l'activitat ens la proposeu encaminada a una nota d'examen, es fa més difícil de practicar. Nosaltres no ens rendim, tractem de reconduir-lo tot el que podem, sovint contra els desitjos d'alguns alumnes que estan per altra cosa, diguem-ne passar l'assignatura. Nosaltres volem fer grup amb els alumnes "ens agrada" aprendre plegats, no com un ramat, no reglats, no tots sabem el mateix de tot, "ens agrada" també respectar estones de libertat i privacitat. Jo vinc a l'escola per estar amb vosaltres, per parlar d'arquitectura."

Y al final del camino me regaló un mensaje claro que me acompaña:

"Treballar per l'arquitectura des de la humilitat i la libertat. Pensant en les persones per construir un món una mica millor".

Las imágenes que aquí presento quieren ilustrar de manera comparada mi trayectoria desde el último curso de proyectos como estudiante en la Accademia de Architettura de Mendrisio hasta los últimos proyectos realizados en el estudio.

Durante estos años he centrado mi trabajo en la construcción de narraciones en el espacio. Una búsqueda basada en la comprensión de lo que hay a nuestro alrededor. Lo que nos forma, o nos conforma, en tanto como personas y siempre con relación a un determinado lugar. Son viajes que van desde la parte más blanda de la arquitectura, los sueños o las intuiciones, hasta la más dura y real, la construida. Un trayecto intuiciones, hasta la más dura y real, la construida. Un trayecto de lo abstracto a lo concreto que durante su proceso sufre las
transformaciones necesarias para crear su cuerpo, su esencia, lo que las cosas son. Hay personas que hablan del alma de las cosas, de su voluntad de ser, quizás estén en lo cierto. Yo lo que intento es poder encontrarla al final del proceso. Todo esto que os cuento son para mí historias que acaban hablando de los sitios, de las culturas y de las técnicas.

Dicho esto, seguir ahora poniéndolo negro sobre blanco es una tarea que no me concierne ni me interesa. Por eso me reservo esta oportunidad de extenderme para dentro de unos años. Por ahora, trataré de dar alguna pista con estas palabras que acompañan mi día a día.

Sensualidad, respeto por el lugar, diseño pragmático, optimización de recursos, formas abiertas, permeabilidad, realidad, poética de las cosas, búsqueda de potenciales, sistemas, nuevos lenguajes.

JORGE VIDAL es Arquitecto por la ETSAB. Entre 2008 y 2018 fue profesor Asociado del Departamento de Proyectos Arquitectónicos de la ETSAB, Universidad Politécnica de Catalunya (UPC).
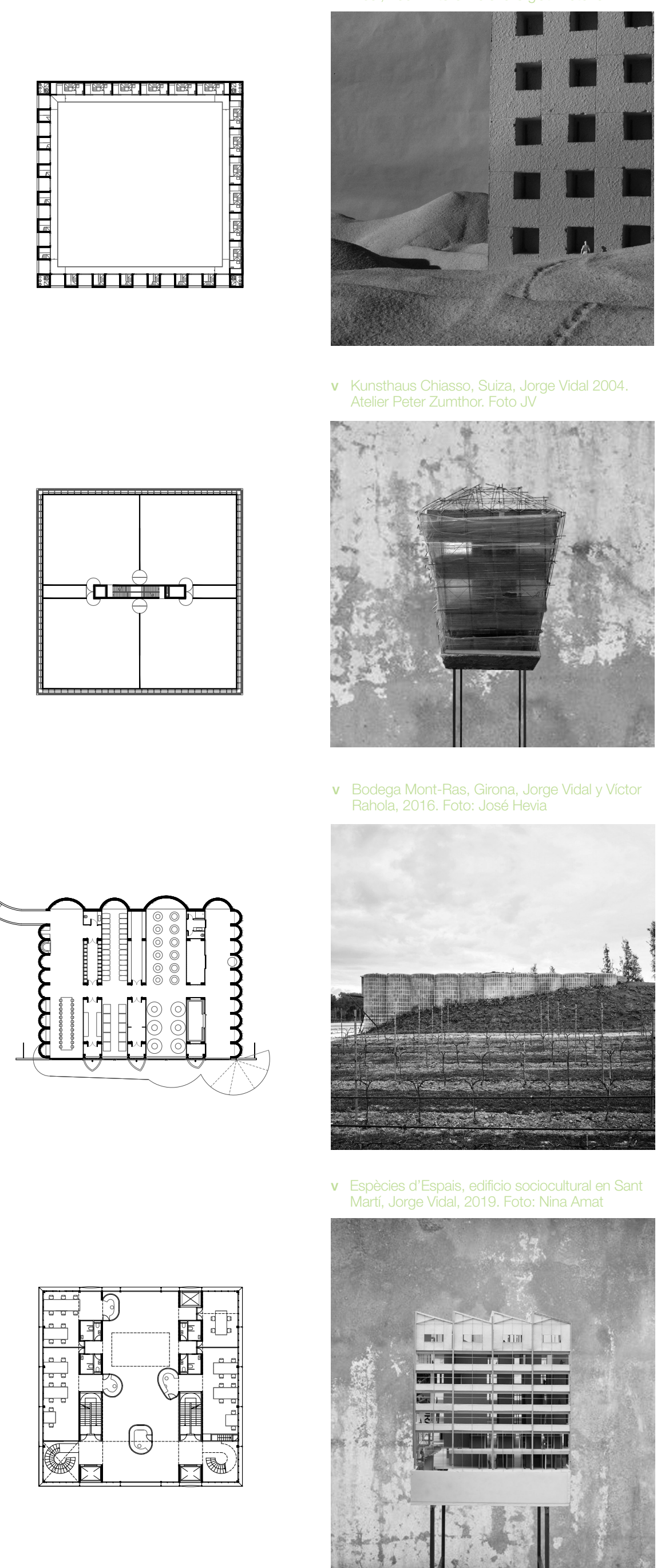